\title{
PENERAPAN METODE SQ3R DAN METODE PQ3R TERHADAP KETERAMPILAN MEMBACA PADA MAHASISWA
}

\author{
${ }^{1)}$ Rini Agustina, ${ }^{2)}$ Hariyadi \\ 1) 2) IKIP PGRI Pontianak \\ E-mail: brentex32@yahoo.co.id
}

\begin{abstract}
ABSTRAK
Penelitian ini bertujuan untuk mendeskripsikan pengaruh penerapan metode SQ3R dan metode PQ3R terhadap keterampilan membaca mahasiswa. Penelitian ini menggunakan metode eksperimen, bentuk penelitian Quasi Eksperimental Design dengan rancangan Nonequivalent Control Group Design. Populasi dalam penelitian ini adalah seluruh mahasiswa Program Studi Pendidikan Bahasa dan Sastra Indonesia semester 6 yang berjumlah 243. Sampel yang digunakan yaitu kelas C Pagi dan kelas C sore yang diperoleh dengan Teknik simple random sampling. Teknik yang digunakan yaitu pengukuran dengan alatnya berupa tes membaca berupa pilihan ganda yang berjumlah 30 butir soal. Teknik analisis data yang digunakan dalam penelitian ini adalah anava 2 jalur. Berdasarkan hasil analisis data, diketahui bahwa penerapan metode SQ3R dan Metode PQ3R tergolong baik dengan rincian sebagai berikut: (1) Nilai rata-rata sebelum diberikan perlakuan 20,476 dengan kategori cukup; (2) rata-rata penerapan metode SQ3R sebesar 22,097 dengan katergori baik; (3) persentase rata-rata metode PQ3R sebesar 22,045 denga kategori baik.
\end{abstract}

Kata kunci: metode SQ3R, metode PQ3R, membaca

\begin{abstract}
This study aims to describe the effect of application of SQ3R method and PQ3R method to students' reading skill. This research uses experimental method, Quasi Experimental Design research form with Nonequivalent Control Group Design design. Population in this research is all student of Study Program of Language and Literature of Indonesia semester 6 which amounted to 243. The sample used is class C Morning and class C afternoon obtained by simple random sampling technique. The technique used is the measurement with the tool in the form of reading test in the form of multiple choice which amounted to 30 items. Data analysis technique used in this research is anava 2 lane. Based on the result of data analysis, it is known that the application of SQ3R method and PQ3R method is good with the details as follows: (1) The average value before given treatment 20,476 with enough category; (2) the average application of the SQ3R method is 22.097 with good category; (3) the average percentage of PQ3R method is 22,045 with good category.
\end{abstract}

Keywords: method SQ3R, PQ3R method, read 


\section{PENDAHULUAN}

Sejalan dengan perkembangan ilmu pengetahuan dan teknologi yang pesat, terutama dalam teknologi percetakan maka semakin banyak informasi yang tersimpan di dalam buku. Pada semua jenjang pendidikan, kemampuan membaca menjadi skala prioritas yang harus dikuasai mahasiswa. Membaca merupakan jendela dunia, siapa pun yang membuka jendela tersebut dapat melihat dan mengetahui segala sesuatu yang terjadi. Baik peristiwa yang terjadi pada masa lampau, sekarang, bahkan yang akan datang.

Begitu pentingnya membaca sehingga keterampilan membaca menjadi keterampilan yang sangat penting dikuasai oleh mahasiswa (Utami, 2017). Mahasiswa harus sudah terbiasa dengan kegiatan membaca karena sebagai mahasiswa memang dituntut untuk rajin membaca.

Seperti yang dikatakan oleh Hodgson (Tarigan, 2008), membaca adalah proses yang dilakukan dan dipergunakan oleh pembaca untuk memperoleh pesan yang hendak disampaikan oleh penulis melalui media kata-kata atau bahasa tulis. Pernyataan yang hampir sama juga diungkapkan Somadayo (2011), membaca adalah suatu kegiatan interaktif untuk memetik serta memahami arti yang terkandung di dalam bahan tulis.

Namun sebuah persoalan membaca yang selalu mengemuka, terutama di kalangan mahasiswa adalah bagaimana cara menimbulkan minat dan kebiasaan membaca. Masalah keterampilan membaca juga yang ditemukan pada mahasiswa IKIP PGRI Pontianak khususnya program Studi Pendidikan Bahasa dan Sastra Indonesia. Berdasarkan hasil pengamatan dan hasil wawancara diketahui bahwa banyak mahasiswa yang kurang tertarik dan kurang memiliki minat maupun keterampilan untuk membaca. Apalagi membaca buku pelajaran. 
Faktor yang menjadi penyebab kurangnya minat mahasiswa untuk membaca: pertama karena kemajuan teknologi yang membuat mahasiswa hanya tinggal copi paste dari internet untuk mengerjakan tugas yang diberikan dosen. Kedua waktu yang terlalu lama-lama membaca menjadi mengantuk; ketiga merasa bosan dengan bacaan yang terlalu panjang dan dengan gaya bahasanya baku.

Masalah yang telah dipaparkan di atas tentu saja harus diberikan solusi agar minat mahasiwa dalam membaca menjadi tinggi. Adapaun solusi yang peneliti berikan adalah dengan menerapkan metode SQ3R dan Metode PQ3R. dengan penerapan kedua metode ini peneliti dapat mengetahui metode mana yang lebih baik, atau mungkin kedua metode ini sama-sama baik untuk memperbaiki keterampilan membaca mahasiswa.

Dari berbagai metode membaca yang berkembang dewasa ini, metode SQ3R (Survey, Question, Read, Recite, dan Review) dan metode PQ3R (Practice, Question, Read, Recite, dan Review) yang akan menjadi fokus dalam penelitian ini. Alasan memilih metode tersebut karena metode SQ3R dan metode PQ3R memiliki langkahlangkah yang sangat memungkinkan untuk dapat memudahkan siswa memahami informasi yang ada dalam teks.

Metode SQ3R adalah model pembelajaran yang menuntun mahasiswa untuk memahami materi pelajaran secara sistamatis, meningkatkan keaktifan, dan kemandirian mahasiswa serta memudahkan mahasiswa belajar, karena model ini terarah langsung pada intisari yang ada pada pokok kajian (Susanti , \& Yulita, 2016). Metode membaca SQ3R dapat meningkatkan perolehan nilai membaca karena metode ini menuntun siswa untuk menyelidiki; judul dan subjudul, membuat pertanyaan, membaca, menyatakan ide-ide pokok yang sudah dibaca dan mengulang kembali bacaan tersebut (Suandi, 2013). Metode SQ3R dapat ditinjau dari aspek proses dalam melakukan aktivitas 
membaca tampak sangat sistematis sehingga diasumsikan penerapan metode SQ3R dapat meningkatkan keterampilan membaca pemahaman mahasiswa. Metode SQ3R merupakan proses membaca sistematik yang meliputi tahap Survey, Question, Read, Recite, dan Review (Suandi \& Putrayasa, 2013).

Selain metode SQ3R yang menjadi objek dalam penelitian ini adalah metode PQ3R. Metode ini juga hampir sama dengan metode SQ3R oleh karena itu peneliti ingin mengetahui apakah metode PQ3R akan memiliki hasil yang sama dengan metode SQ3R. Menurut Ibda (2017), PQ3R (prepare, question, reading, recite and review). Perbedaannya hanya terletak pada langkah awalnya saja. SQ3R didahului dengan survai, sedangkan PQ3R didahului dengan prepare. Prepare adalah tahap mula dalam membaca sebuah buku dengan cara melihat secara sekilas terhadap keseluruhan sebuah buku. Tahap ini diperlukan untuk pemanasan atau persiapan tahap berikutnya dan untuk penjajakan terhadap isi buku. Berdasarkan paparan yang telah dikemukakan, maka tujuan penelitian ini adalah untuk mengetahui pengaruh metode SQ3R dan Metode PQ3R terhadap keterampilan membaca?

\section{METODE}

Metode yang dugunakan dalam penelitian ini yaitu metode eksperimen dan bentuk penelitian Quasi Eksperimental Design dengan rancangan Nonequivalent Control Group Design. Populasi dalam penelitian ini adalah seluruh mahasiswa program Studi Pendidikan Bahasa dan Sastra Indonesia semester 6 yang berjumlah 243. Sampel yang digunakan yaitu kelas $\mathrm{C}$ Pagi dan kelas $\mathrm{C}$ sore yang diperoleh dengan Teknik simple random sampling. Teknik yang digunakan yaitu pengukuran dengan alat pengumpul datanya berupa tes keterampilan membaca melalui tes objektif berupa pilihan ganda 
yang berjumlah 30 butir soal. Teknik analisis data yang digunakan dalam penelitian ini adalah anava 2 jalur.

\section{HASIL DAN PEMBAHASAN}

Penelitian yang telah dilakukan ini bertujuan untuk mengetahui: (1) keterampilan membaca mahasiswa sebelum diberikan perlakuan; (2) keterampilan membaca mahasiswa yang diberikan metode SQ3R; (3) keterampilan membaca mahasiswa yang diberikan metode PQ3R; dan (4) perbedaan keterampilan membaca antara mahasiswa yang diberikan metode SQ3R dengan metode PQ3R.

Data berikut ini merupakan nilai dari keterampilan memabaca mahasiswa sebelum diberikan perlakuan disetiap kelas. Adapun rincian tentang hasil dari pretest (keterampilan membaca mahasiswa) sebelum diberikan perlakukan adalah sebagai berikut ini.

Tabel 1. Data Keterampilan Membaca Mahasiswa Sebelum Perlakuan

\begin{tabular}{|c|c|c|c|c|c|c|}
\hline \multirow{3}{*}{ Deskripsi } & \multicolumn{6}{|c|}{ Kelas } \\
\hline & \multicolumn{2}{|c|}{ C sore } & \multicolumn{2}{|c|}{ C pagi } & \multicolumn{2}{|c|}{ B Sore } \\
\hline & Nilai & $100 \%$ & Nilai & $100 \%$ & Nilai & $100 \%$ \\
\hline Nilai Tertinggi & 26 & 86.667 & 25 & 83.333 & 26 & 86.667 \\
\hline Nilai Terendah & 9 & 30 & 12 & 40 & 9 & 30 \\
\hline Rata-rata & 19.516 & 65.054 & 20.81 & 69.365 & 20.095 & 66.984 \\
\hline Median & 20 & 66.667 & 21 & 70 & 22 & 73.3333 \\
\hline Modus & 19 & 63.333 & 25 & 83.33 & 22 & 73.33 \\
\hline Varian & 22.258 & 247.312 & 10.938 & 121.54 & 19.844 & 220.49 \\
\hline Simpangan Baku & 4.718 & 15.726 & 3.307 & 11.02 & 4.455 & 14.85 \\
\hline
\end{tabular}

Berdasarkan data penelitian yang didapat, untuk nilai keterampilan membaca mahasiswa yang diberikan metode pembelajaran SQ3R diperoleh hasil dengan skor tertinggi 27 dan terendah 16. Mean (skor rata-rata) 22,097; median (nilai tengah) 22; modus (skor yang memiliki frekuensi terbanyak) 26; varians data ini adalah 10,824; dan 
simpangan baku sebesar 3,290. Harga-harga statistik tersebut lebih lengkap diuraikan dalam tabel berikut ini.

Tabel 2.

Deskripsi Nilai Keterampilan Membaca Mahasiswa yang diberikan metode SQ3R

\begin{tabular}{|l|c|c|}
\hline \multicolumn{1}{|c|}{ Deskripsi } & Skor & $\mathbf{1 0 0 \%}$ \\
\hline Nilai Tertinggi & 27 & 90 \\
\hline Nilai Terendah & 16 & 53.333 \\
\hline Nilai Rata-rata & 22.097 & 73.656 \\
\hline Median & 22 & 73.333 \\
\hline Modus & 26 & 86.667 \\
\hline Varian data & 10.824 & 120.263 \\
\hline Simpangan Baku & 3.290 & 10.966 \\
\hline
\end{tabular}

Berdasarkan data penelitian yang didapat, untuk nilai keterampilan membaca mahasiswa yang diberikan metode pembelajaran PQ3R diperoleh hasil dengan skor tertinggi 28 dan terendah 18. Mean (skor rata-rata) 22,405; median (nilai tengah) 22; modus (skor yang memiliki frekuensi terbanyak) 24; varians data ini adalah 6,881; dan simpangan baku sebesar 2,623. Harga-harga statistik tersebut lebih lengkap diuraikan dalam table berikut ini.

Tabel 3.

Deskripsi Nilai Keterampilan Membaca Mahasiswa yang diberikan metode PQ3R

\begin{tabular}{|l|r|r|}
\hline \multicolumn{1}{|c|}{ Deskripsi } & \multicolumn{1}{c|}{ Skor } & \multicolumn{1}{c|}{$\mathbf{1 0 0 \%}$} \\
\hline Nilai Tertinggi & 28 & 93.333 \\
\hline Nilai Terendah & 18 & 60 \\
\hline Nilai Rata-rata & 22.405 & 74.683 \\
\hline Median & 22 & 73.333 \\
\hline Modus & 24 & 80 \\
\hline Varian data & 6.881 & 76.455 \\
\hline Simpangan Baku & 2.623 & 8.744 \\
\hline
\end{tabular}


Berdasarkan data penelitian yang didapat, untuk nilai keterampilan membaca mahasiswa kelas kontrol ini diperoleh hasil dengan skor tertinggi 26 dan terendah 14. Mean (skor rata-rata) 20,476; median (nilai tengah) 20; modus (skor yang memiliki frekuensi terbanyak) 19; varians data ini adalah 11,816; dan simpangan baku sebesar 3,438. Harga-harga statistik tersebut lebih lengkap diuraikan dalam table berikut ini.

Tabel 4.

Deskripsi Nilai Keterampilan Membaca Mahasiswa yang tidak Diberikan Perlakuan (Kelas Kontrol)

\begin{tabular}{|l|r|r|}
\hline \multicolumn{1}{|c|}{ Deskripsi } & \multicolumn{1}{c|}{ Skor } & \multicolumn{1}{c|}{$\mathbf{1 0 0 \%}$} \\
\hline Nilai Tertinggi & 26 & 86.667 \\
\hline Nilai Terendah & 14 & 46.667 \\
\hline Nilai Rata-rata & 20.476 & 68.254 \\
\hline Median & 20 & 66.667 \\
\hline Modus & 19 & 63.333 \\
\hline Varian data & 11.816 & 131.294 \\
\hline Simpangan Baku & 3.438 & 11.458 \\
\hline
\end{tabular}

Uji normalitas dilakukan untuk mengetahui apakah data dalam penelitian ini berdistribusi normal atau tidak. Dalam penelitian ini, data yang dimaksudkan adalah data variabel keterampilan membaca mahasiswa pada kelas eksperimen yaitu kelas $\mathrm{C}$ Sore menggunakan metode SQ3R dan C Pagi menggunakan metode PQ3R, dan pada kelas kontrol yaitu kelas B Sore yang tidak diberikan perlakuan. pengujian normalitas data ini dilakukan dengan teknik Lilliefors. Analisis data ini menggunakan bantuan program SPSS. Adapun hasilnya dapat dilihat dalam tabel berikut ini. 
Tabel 5. Hasil Uji Normalitas

\begin{tabular}{|ll|r|r|r|r|r|r|}
\hline & & \multicolumn{1}{c|}{ Tests of Normality } \\
\cline { 2 - 7 } & Faktor & Statistic & \multicolumn{1}{c|}{ Df } & \multicolumn{1}{c|}{ Sig. } & Statistic & \multicolumn{1}{c|}{ Df } & Sig. \\
\cline { 2 - 7 } & Eksperimen SQ3R & .138 & 31 & .139 & .937 & 31 & .068 \\
\hline $\begin{array}{l}\text { Keterampilan Membaca } \\
\text { Mahasiswa }\end{array}$ & Eksperimen PQ3R & .109 & 42 & $.200^{*}$ & .966 & 42 & .240 \\
& Kontrol & .120 & 42 & .136 & .952 & 42 & .078 \\
\hline
\end{tabular}

a. Lilliefors Significance Correction

*. This is a lower bound of the true significance.

Berdasarkan hasil pengujian yang telah dilakukan, diperoleh untuk kelas eksperimen SQ3R dan PQ3R masing-masing sebesar $\rho=0,068$ dan $\rho=0,0240$ sehingga $\rho>\alpha$, dan untuk kelas control diperoleh nilai signifikansi sebesar $\rho=0,078$ sehingga $\rho$ $>\alpha$. Dengan demikian Ho diterima, sehingga sampel berasal dari populasi yang berdistribusi normal.

Dengan taraf siginifikansi 0,05, rangkuman hasil uji homogenitas variansi populasi menggunakan uji Bartlett dan bantuan program SPSS terhadap data keterampilan membaca mahasiswa disajikan dalam Tabel 5.

Tabel 6. Hasil Uji Homogenitas Variansi data

Test of Homogeneity of Variances

Keterampilan Membaca Mahasiswa

\begin{tabular}{|r|r|r|l|}
\hline Levene Statistic & df1 & df2 & Sig. \\
\hline 1.889 & 2 & 112 & .156 \\
\hline
\end{tabular}

Berdasarkan hasil uji homogenitas variansi populasi pada Tabel 6. di atas, diperoleh nilai sig $=0,156>0,05$. Hal ini berarti pada taraf signifikansi 0,05 , keputusan uji homogenitas variansi populasi adalah data keterampilan membaca mahasiswa diambil dari sampel yang homogen. 
Pengujian hipotesis dimaksudkan untuk melihat apakah ada perbedaan yang signifikan keterampilan membaca antara mahasiswa yang diberikan metode SQ3R dengan metode PQ3R. Sesuai dengan hipotesis yang diajukan, maka hasil pengujian tersebut akan dipaparkan berikut ini.

Tabel 7.

Tests of Between-Subjects Effects

Dependent Variable:Nilai

\begin{tabular}{|l|r|r|r|r|r|}
\hline Source & $\begin{array}{r}\text { Type III Sum of } \\
\text { Squares }\end{array}$ & df & Mean Square & \multicolumn{1}{c|}{ F } & \multicolumn{1}{c|}{ Sig. } \\
\hline Corrected Model & $87.860^{\mathrm{a}}$ & 2 & 43.930 & 4.509 & .013 \\
Intercept & 52857.506 & 1 & 52857.506 & $5.425 \mathrm{E} 3$ & .000 \\
Kelas & 87.860 & 2 & 43.930 & 4.509 & .013 \\
Error & 1091.305 & 112 & 9.744 & & \\
Total & 54920.000 & 115 & & & \\
Corrected Total & 1179.165 & 114 & & & \\
\hline
\end{tabular}

Interpret asi tabel:

a. Corr ected a. R Squared $=.075$ (Adjusted R Squared $=.058$ )

el

Dari koreksi model ini dapat diketahui seberapa besar pengaruh variabel bebas terhadap variabel terikat. Dalam hal ini, variabel bebas yaitu faktor-faktor yang akan diukur oleh peneliti yaitu berupa nilai mahasiswa dari tiga kelas yang telah dilakukan penelitian. Dari tabel di atas bisa dilihat berdasarkan nilai (sig), bila sig $<0,05$ yaitu $(0,013<0,05$ berarti model yang diperoleh adalah valid.

Nilai intercept dalam hal ini merupakan nilai mahasiswa pada keterampilan membaca. Dari tabel di atas dapat dilihat berdasarkan nilai (sig), bila nilai sig $<0,05$ yaitu $(0,000<0,05)$ berarti intercept ini berkontribusi secara signifikan.

Uji beda rata-rata berdasarkan metode pembelajaran. Adapun hipotesis yang diajukan adalah sebagai berikut:

Ho = Tidak ada perbedaan rata-rata hasil belajar dari metode SQ3R, metode PQ3R, dan kelas yang tanpa perlakuan. 
$\mathrm{Ha}=$ Ada perbedaan rata-rata hasil belajar dari dari metode SQ3R, metode PQ3R, dan kelas yang tanpa perlakuan.

Nilai yang digunakan disini adalah nilai probabilitas pada kolom Sig. Apabila nilai probabilitas $>$ 0,05 maka Ho diterima. Sebaliknya, jika nilai probabilitas $<0,05$ maka Ho ditolak. Berdasarkan output tersebut diperoleh probabilitas 0,000. Karena $0,013<0,05$ maka Ho ditolak dan Ha diterima. Sehingga, dengan menggunakan taraf signifikansi 0,05 maka dapat disimpulkan bahwa ada perbedaan rata-rata hasil belajar dari dari metode SQ3R, metode PQ3R, dan kelas yang tanpa perlakuan.

Uji interaksi ini bertujuan untuk mengetahui apakah ada pengaruh yang signifikan antara nilai keterampilan membaca mahasiswa dari ketiga kelas tersebut. Hipotesis:

Ho : tidak ada interaksi yang signifikan antara nilai keterampilan membaca mahasiswa dari ketiga kelas.

$\mathrm{H}_{1}$ : ada interaksi antara nilai keterampilan membaca mahasiswa dari ketiga kelas.

Pengambilan keputusan:

Jika $\mathrm{F}$ hitung $<\mathrm{F}$ tabel atau nilai sig $>0,05$, maka Ho diterima

Jika $\mathrm{F}$ hitung $>\mathrm{F}$ tabel atau nilai sig $<0,05$, maka Ho ditolak, jadi $\mathrm{H}_{1}$ diterima.

Keputusan:

Dari tabel di atas terlihat bahwa nilai $\mathrm{F}$ hitung 4,509 dan $\mathrm{F}$ tabel 3,08 (F tabel terlampir) atau nilai signifikan yang diperoleh dari tabel tersebut sebesar 0,013. Jadi dapat disiampulkan: $\mathrm{H}_{1}$ diterima dan ada interaksi antara nilai keterampilan membaca mahasiswa dari ketiga kelas.

Dari tabel di atas terlihat bahwa nilai $\mathrm{F}$ hitung 4,509 dan $\mathrm{F}$ tabel 3,08 (F tabel terlampir) atau nilai signifikan yang diperoleh dari tabel tersebut sebesar 0,013. Jadi 
dapat disiampulkan: $\mathrm{H}_{1}$ diterima dan ada interaksi antara nilai keterampilan membaca mahasiswa dari ketiga kelas.

Hasil ini bermakna bahwa metode pembelajaran yang diberikan memberikan pengaruh terhadap keterampilan membaca mahasiswa secara signifikan. Dalam hal ini, metode SQ3R dan PQ3R juga terdapat perbedaan berdasarkan hasil uji beda.

Adapaun deskripsi kategori nilai tersebut sebagai berikut ini.

\section{Tabel 8.}

Kategori nilai Rata-rata keterampilan membaca mahasiswa

\begin{tabular}{|c|c|c|c|}
\hline Kelas & Nilai & Persentase & Keterangan \\
\hline C Sore (SQ3R) & 22,097 & 73,656 & Baik \\
C Pagi (PQ3R) & 22,405 & 74,683 & Baik \\
B Sore (Kelas Kontrol) & 20,476 & 68,254 & Cukup \\
\hline
\end{tabular}

Tabel di atas menunjukkan adanya perbedaan rata-rata keterampilan membaca mahasiswa. Dalam hal ini kelas C Sore dan C Pagi yang sama-sama diberikan perlakuaan mendapatkan nilai persentase dan kategori yaitu Baik. Sedangkan kelas B Sore yang tidak diberikan perlakuan mendapatkan nilai rata-rata dengan kategori Cukup.

\section{KESIMPULAN}

Berdasarkan penelitian yang telah dilakukan dapat disimpulkan bahwa (a) keterampilan membaca mahasiswa sebelum diberikan perlakuan tergolong cukup, (b) keterampilan membaca mahasiswa yang diberikan metode SQ3R tergolong baik, (c) keterampilan mahasiswa yang diberikan metode PQ3R tergolong baik, (d) tidak terdapat 
perbedaan yang signifikan antara mahasiswa yang diberikan metode SQ3R dan mahasiswa yang diberikan metode PQ3R.

\section{UCAPAN TERIMA KASIH}

Terima kasih kepada berbagai pihak yang telah mendukung penyusunan dan publikasi penelitian ini

\section{DAFTAR PUSTAKA}

Haryadi. (2012). Retorika membaca (model, metode, teknik). Semarang: Rumah Indonesia.

Ibda, H. (2018). Gerakan metal (membaca artikel) untuk meningkatkan kemampuan membaca kritis guru MI. MAGISTRA: Media Pengembangan Ilmu Pendidikan Dasar dan Keislaman, 8 (1).

Suandi, I. N., \& Putrayasa, I. B. (2013). Pengaruh Penerapan Metode SQ3R dan Teknik Klose terhadap Kemampuan Membaca Pemahaman Siswa. Jurnal Pendidikan Bahasa Indonesia, 2.

Susanti, S., \& Yulita, D. P. S. (2016). Pengaruh Penerapan Metode Pembelajaran SQ3R (Survey, Question, Read, Recite, And Review) Terhadap Hasil Belajar Mahasiswa Prgram Studi Pendidikan Sejarah IKIP PGRI Pontianak. Edukasi: Jurnal Pendidikan, 13(1), 97-104.

Somadyo. (2011) Membaca. Sidoarjo: Masmedia Buana Pustaka.

Tarigan, H.G. (2008) Membaca: sebagai Suatu Keterampilan Berbahasa. Bandung: Angkasa.

Utami, S. R. (2017). Pembelajaran Aspek Tata Bahasa dalam Buku Pelajaran Bahasa Indonesia. Aksis: Jurnal Pendidikan Bahasa dan Sastra Indonesia, 1(2). 189203. doi: doi.org/10.21009/AKSIS.010203 